Article

\title{
Managing Super-Diversity on Television: The Representation of Ethnic Minorities in Flemish Non-Fiction Programmes
}

\author{
Koen Panis *, Steve Paulussen and Alexander Dhoest \\ Department of Communication Studies, University of Antwerp, 2000 Antwerp, Belgium; E-Mails: \\ koen.panis@uantwerpen.be (K.P.), steve.paulussen@uantwerpen.be (S.P.), alexander.dhoest@uantwerpen.be (A.D.) \\ * Corresponding author
}

Submitted: 15 June 2018 | Accepted: 6 August 2018 | Published: 5 February 2019

\begin{abstract}
This study examines and evaluates the representation of ethnocultural diversity in non-fiction TV programmes broadcasted by the Flemish (Belgian Dutch-speaking) public service broadcaster VRT in the 2016-2017 TV season. A qualitative content analysis of a sample comprising 36 clips and episodes of 14 non-fiction programmes was supplemented by four focus group interviews with a total of 12 participants belonging to different ethnocultural minorities. The findings suggest that despite several measures undertaken by the VRT, the representation of ethnocultural minorities is still unbalanced and biased in at least three ways: first, in presenting minorities as homogeneous groups rather than highlighting intragroup differences; second, in 'typecasting' people with a migration background thematically, i.e., for items on topics and issues related to their ethnocultural identity; and, third, in portraying and approaching minorities from a dominant group perspective. The article ends with the recommendation for public service media to further improve ethnocultural diversity in the workforce and to encourage their journalists and TV producers to reconsider their 'professional pragmatics' in order to increase their ethnocultural sensitivity and better manage the representation of super-diversity in their programmes.
\end{abstract}

\section{Keywords}

ethnic minorities; ethnocultural diversity; media representation; non-fiction programmes; public service media; super-diversity; television

\section{Issue}

This article is part of the issue "Communicating on/with Minorities", edited by Leen d'Haenens and Willem Joris (KU Leuven, Belgium).

(C) 2019 by the authors; licensee Cogitatio (Lisbon, Portugal). This article is licensed under a Creative Commons Attribution 4.0 International License (CC BY).

\section{Introduction}

In today's digital age, most people still rely heavily on mainstream media content to inform themselves and learn about society. According to the Reuters Institute Digital News Report, also in high-choice media environments, television is the main source of news for many, and while people are increasingly consuming news on the Internet, the online news sources they use are often websites and apps of legacy newspapers and television channels (Newman, Fletcher, Kalogeropoulos, Levy, \& Nielsen, 2017). As mainstream media remain key sources of information, they carry a great responsibility in the mediated construction and representation of society in its diversity. This is particularly the case for public service media (PSM), which for many "still represent a normative vision of what mainstream media ought to strive to achieve in terms of pluralism and societal representation" (Horsti, Hultén, \& Titley, 2014, p. 3). PSM therefore tend to reflect dominant political and social discourses on cultural diversity. In Europe's contemporary migration societies this means that PSM have been given an important role in promoting and supporting the 'integration' of immigrants and social cohesion among ethnic majority and minority groups (Horsti et al., 2014; Titley, 2014).

In Flanders, the Dutch-speaking northern part of Belgium, the public service broadcaster VRT signed a Diversity Charter in 2003, which "signalled the official start 
of cultural diversity policies at the VRT" (Dhoest, 2014, p. 112). In the same year, a Diversity Cell was established, consisting of two staff members tasked with monitoring and stimulating diversity both in the TV and radio programmes and within the workforce of the VRT. An important initiative of the Diversity Cell was the creation of a Diversity Monitor to measure the portrayal of persons with different ability levels, gender, ethnocultural and religious backgrounds in TV programmes of the VRT. While this quantitative monitoring of the mere presence of minorities on television has helped the VRT to achieve government-imposed targets (Dhoest, 2015), the Diversity Cell is aware that quantitative measures do not show the whole picture. Therefore, in 2017, the VRT commissioned a qualitative study to analyse and critically evaluate the representation of ethnic minorities in its television programmes. Whereas the study, independently conducted by the authors of this article, included a sample of both fiction and non-fiction programmes, the article at hand only focuses on the data and findings concerning the VRT's news, current affairs, documentary and talk show programmes. More specifically, the study employs a multimethod research design in which a qualitative content analysis of a selection of 14 non-fiction programmes broadcasted by the VRT in the 2016-2017 TV season is combined with focus group interviews with 12 expert members of different ethnic minority groups. The combination of content analysis and focus group interviews allows us to provide a nuanced and profound description and evaluation of the way in which the journalists and programme makers at VRT account for and deal with ethnic diversity in the process of TV production.

Before discussing our findings and recommendations, we situate our study within the current body of literature on (public service) media and diversity. We argue that the debate on PSM's role in representing ethnic diversity is shifting from a paradigm focused on the 'recognition of multiculturalism' to one focused on the 'management of super-diversity', which urges us to pay more attention to the production context in which the 'politics of diversity' are, can and should be translated and integrated into the norms and work practices of TV professionals.

\section{Literature Review}

\subsection{Media, Multiculturalism and Super-Diversity}

Debates on the role of (public service) media should always be considered within the broader policy context and political discourse. When democracies in Europe and elsewhere began to develop policies on 'multiculturalism' from the 1970s onwards, the 'paradigm of diversity' also entered PSM debates. Struggling with their legitimacy in an era of increased access to information technologies and fierce competition from commercial media, public service broadcasters became more aware of the distinctive role they could play in the recognition of mul- ticulturalism (Horsti et al., 2014). This resulted in multicultural programming and efforts to include marginalised voices in media representations of diversity (Leurdijk, 2006). By the end of the twentieth century, the notion of 'multiculturalism' began to be replaced by the broader idea of 'cultural diversity' (Malik, 2013). Instead of focusing on programmes that explicitly addressed ethnic voices and topics, a more inclusive approach was taken to produce programmes with rather than about members of minority groups. Also, PSM began to broaden their attention from on-screen diversity to diversity behind the screen (cf. Ofcom, 2017). As a result, within PSM in Europe, diversity is nowadays "understood as a series of commitments to 'diversify' across three key areas: in programming (questions of representation and plurality of voice), in employment, and in organizational development (training people to appreciate/learn from diversity)" (Horsti et al., 2014, p. 10, italics in original).

Literature on the representation of ethnocultural diversity in television programming points out three major problems or concerns. First, study after study has shown an under-representation of certain minorities in media content, which may lead to their 'symbolic annihilation' (Gerbner \& Gross, 1976). If certain groups are less visible on television, they and their concerns are more likely to go unnoticed by society. In the past, media and policymakers have responded to this issue by imposing diversity targets to ensure the recognition of the ethnocultural diversity within society. While it remains important to strive for a statistically accurate reflection of reality, such quantitative strategies have possible sideeffects, including 'box ticking' (Leurdijk, 2006) and 'tokenism' (Hodkinson, 2011). Some authors also suggest that quantitative strategies are insufficient to address the 'burden of representation', that is, the expectation placed on members of minority groups to stand for the entire community they are supposed to represent. Although this burden of representation is likely to decrease if it is spread over a larger number of 'role models', individuals who appear on television may still feel pressured to adhere to certain role expectations that come from both their own minority community and the dominant group(s) in society (Dwyer, 1998, p. 60; Hodkinson, 2011).

A second problem in media representations of diversity is that media's portrayal of minority groups and minority-related issues is characterised by stereotyping and a negativity bias. Hodkinson (2011) notes that "stereotypical depictions of ethnic minorities have been a constant feature of the history of media content" (p. 201). One of the most recent forms of stereotyping in European media reporting is how people with origins in Africa and the Middle East are often associated with Islam, extremism and terrorism. Stereotypes and onesided negative images of ethnic minorities lead to stigmatisation and us/them polarisation (Shadid, 2005), which relate to the phenomena of 'everyday racism', xenophobia and Islamophobia (Essed, 1991; Saeed, 2007; van Dijk, 2000). The negativity bias also results in the 'ghet- 
toization' of ethnic minorities, i.e., the tendency to report on minorities in relation to problems and threats (Haynes, 2007, pp. 175-176). A large body of research shows that media coverage about ethnic minorities emphasises topics such as violence, crime, drugs, unemployment, poverty, and, more recently, religion and fundamentalism (ter Wal, d'Haenens, \& Koeman, 2005).

A third concern regarding the media's representation of ethnocultural diversity deals with the implicit normativity of 'whiteness' in media discourse. Dyer (1997) introduced the concept of 'whiteness' to indicate that in Western societies, most social and political issues tend to be approached from the perspective of white people, implying that 'people of colour' represent the 'other' whereas whiteness constitutes the taken-for-granted, invisible norm. Several authors have shown how media tend to adopt this us/them dichotomy to distinguish between the white majority and ethnic minorities, thus reflecting and reinforcing the cultural inequalities in society (Blommaert \& Verschueren, 1998; Ferguson, 1998).

It should be noted that media, and particularly PSM, are increasingly aware of the problems of underrepresentation, stereotypical portrayal and white normativity in media coverage on ethnic minorities. In reaction to these issues, they engage in efforts to pay more attention to 'diversity within diversity'. This points at a paradigm shift away from the concept of 'multiculturalism', that has repeatedly been criticised for its tendency "to flatten thinking about cultural heterogeneity" (Cottle, 2000, p. 29), towards new paradigms that give more room to thinking about 'intersectionality' and 'interculturality'. These concepts highlight the multiple identities of people, urging media to acknowledge that members of minority groups never belong to just one social group. Media should therefore pay more attention to different 'intersections' between ethnicity and other identity factors such as age, gender, sexual orientation, religion, etc. (Crenshaw, 1989).

To account for the internal heterogeneity between and within different ethnic minority groups, Vertovec (2007) proposes a framework of 'super-diversity', suggesting that policymakers and practitioners should "avoid the conventional trap of addressing newcomers just in terms of some presumably fixed ethnic identity" (p. 1048) and acknowledge the intra-cultural "plurality of affiliations" (p. 1048) among migrant and ethnic minority groups. Whereas the politics of multiculturalism encouraged media to focus on 'collective identities' and on commonalities rather than differences between majority and minority groups, the concept of 'super-diversity' accepts and emphasises the cultural heterogeneity and voice plurality within and among ethnic minority communities. Moreover, super-diversity requires (public service) media to shift away from the mere 'recognition' of the multicultural character of social reality towards an increased awareness that ethnocultural diversity needs to be managed. This relates to what Horsti et al. (2014) refer to as 'organizational development', suggesting that actions need to be taken to raise awareness and train people within the organisation to develop a sensitivity for diversity within their daily work practices.

\subsection{The 'Professional Pragmatics' of TV Production}

In political discourse, diversity is often regarded as a problem that needs to be managed. According to Blommaert and Verschueren (1998), two forms of diversity management can be distinguished: on the one hand, governments and public services, including PSM, are tasked with the goal of containing diversity by stressing unity, cohesion and collective identities, while, on the other hand, they also have to develop strategies to promote tolerance. Both management strategies still underlie current diversity policies of PSM. However, applied to super-diversity, one can argue that further strategies are needed to ensure that ethnocultural minorities are not being disadvantaged in their access to and presence in TV programmes. One way to do so is by training TV professionals to develop a greater awareness of and sensitivity to 'diversity within diversity'. As Dreher (2009) suggests, such trainings in cultural sensitivity could focus on skills for 'listening across difference' to minority voices, thus "shifting some of the responsibility for change from 'ethnic communities' and on to the institutions and conventions which enable and constrain receptivity and response" (p. 456).

To increase sensitivity to super-diversity requires media to reconsider the 'professional pragmatics' that shape the process of TV production. The concept of 'professional pragmatics' was developed by Cottle (1998) to refer to the practices and strategies used by professionals to deal with organisational goals and governmentimposed targets in the daily work context-i.e., by articulating, rationalising, mediating and circumventing them. Accounting for the role of 'professional pragmatics' allows researchers to see "how unintended as well as intended consequences flow from the ways in which producers respond to, and professionally mediate, difficult internal institutional and external cultural-political circumstances" (Cottle, 1998, pp. 312-313). In other words, to fully understand media representation, we should be aware of the resources, strategies, routines, norms and skills that shape the decisions which practitioners take during the TV production process (see also Cottle, 2000; Van den Bulck \& Broos, 2011). Indeed, as the idea of media as 'managers of diversity' (d'Haenens, 2006) implies the recognition that media professionals play an active role in the selection and portrayal of minorities, it is important to take into account the production context. Hence, this study focuses on the (re)presentation practices of TV journalists and programme makers, and ends with recommendations of how the VRT, and PSM in general, can improve these practices by influencing the 'professional pragmatics' that both enable and constrain the representation of super-diversity in TV nonfiction programmes. 


\section{Case Description: The Flemish Public Service Broadcaster}

Flanders presents an interesting case for the study of ethnocultural diversity in PSM, not only because Belgium, like most European countries, has a colonial past (in Congo and Ruanda-Urundi) and became a migration society in the second half of the twentieth century, but also because the region is a stronghold of PSM, with the VRT still taking a market leader position (Dhoest, 2014). Because of its reach and impact, politicians are well aware that the VRT can play an important role in promoting values of inclusion, integration and social cohesion. Therefore, the VRT has been urged to develop diversity policies. As mentioned above, a milestone in this respect was the launch of a Diversity Charter in 2003 and the subsequent creation of a Diversity Cell. In the following years, the Diversity Cell undertook different actions to monitor and stimulate diversity in the VRT's programming and organisation.

Despite the undeniably good intentions, the efforts were not immediately successful or visible in the output and organisation of the VRT. Reflecting on the VRT actions concerning ethnic and cultural diversity up to 2010, Dhoest (2014) found that the VRT still fell short of its ambitions regarding the presence of ethnic diversity on and behind the screen. Similarly, a study on the impact of the Diversity Charter on ethnic minority reporting in the newscasts of the VRT concluded that, seven years after its implementation, working within the charter had not resulted in more balanced ethnic minority reporting, due to journalists' and programme makers' unwillingness or incapacity to change their work routines or question their professional norms (Van den Bulck \& Broos, 2011).

However, in recent years, significant progress has been made. After a renewal of the Diversity Charter in 2012, the VRT intensified its efforts to diversify its staff, which has led to an increased number of journalists and programme makers with different ethnic backgrounds behind and on the screen. Also, the VRT decided to avoid usage of the generalising and increasingly stigmatising term 'allochthone' (meaning 'born elsewhere') to refer to persons of foreign origin (Dhoest, 2014). Furthermore, the annual Diversity Monitor shows that since 2012, the VRT has been successful in meeting the diversity benchmarks set out in the Management Agreement between the Flemish government and the public service broadcaster. In the most recent Management Agreement for the 2016-2020 period, these benchmarks stipulate, for instance, that the VRT should strive for $7.5 \%$ of 'new Flemings' in its total TV output (VRT/Flemish Government, 2016). The term 'new Flemings' refers to people born or with at least one parent born outside the EU-15. Recent figures show that $10 \%$ of the Flemish population fits this definition, with $2 \%$ of the population having origins in Turkey and about three percent in countries of the Maghreb (especially Morocco) (Noppe et al., 2018).
Despite the positive reports on the VRT's performance in attending to 'new Flemings' in its programmes, the Diversity Cell is aware that quantitative measures do not allow for much reflection and contextualisation. Therefore, the cell has begun to organise workshops for journalists and programme makers to assess and reflect on their practices and strategies in relation to ethnocultural diversity. In preparation of these workshops, the Diversity Cell commissioned an independent study to critically evaluate its TV programmes and develop recommendations for how the VRT's media professionals can further improve the representation of super-diversity on the Flemish television screen. As mentioned above, the article at hand discusses the findings and recommendations based on the analysis of the non-fiction programmes broadcasted in the 2016-2017 TV season.

\section{Research Design}

This study employs a multimethod research design to investigate and evaluate the construction and representation of ethnocultural diversity in non-fiction programmes of the Flemish public broadcaster VRT. First, in order to describe how ethnocultural diversity is represented on television, we conducted a qualitative content analysis of a sample of non-fiction programmes broadcasted in the 2016-2017 TV season. Second, in order to interpret and evaluate these representations, we organised focus group interviews with 12 expert members of ethnocultural minority groups.

\subsection{Qualitative Content Analysis}

For the qualitative content analysis, we created a nonrandom sample of 36 clips and episodes from 14 nonfiction programmes broadcasted in 2016-2017 on one of VRT's three TV channels (één, Canvas and Ketnet). The programmes selected include the seven-o'clock news programme Het Journaal (8 items), the youth news programme Karrewiet ( 2 items), the current affairs programmes De Afspraak (4 items) and Terzake (4 items), the investigative programme Pano (2 episodes), the talk shows Van Gils \& Gasten (4 clips) and Alleen Elvis Blijft Bestaan (1 episode), the satire show De Ideale Wereld (3 clips), the daily human-interest programme ledereen Beroemd (3 clips), and one episode from the docu-reality programmes Goed Volk, Topservice, Op Weg met Jan, De Klas and Radio Gaga.

We used purposive sampling to select clips and episodes reflective of the variety of ethnic minorities and contexts in which they appear in the totality of the non-fiction TV programmes produced by the VRT in that period. This way, we ensured that our sample also covered those (rare) items in which different ethnic groupscovering the entire range of 'new Flemings'-appear in less typical (or stereotypical) roles and contexts. Consequently, the findings presented below may not be representative for the overall TV output by the VRT, but we 
believe they provide a representative picture of the different ways in which journalists and programme makers at the VRT manage ethnocultural diversity when producing television content.

A systematic qualitative content analysis was performed to describe and interpret how the selected programme items represent ethnic minorities. We analysed their thematic scope and focus (what is the topic of the item, and which aspects of the topic are emphasised or downplayed?), the visual representation of ethnic minorities (which actors are shown, whose voices are included, and how are the actors and voices portrayed?), and the textual representation (how are minority topics and persons talked about, in what wordings and what tone?). The descriptive part of the analysis was carried out by the first author of this article, but discussion between the three authors informed the further interpretation of the findings.

\subsection{Focus Group Interviews}

To deepen and validate the interpretation of the findings of the content analysis, we decided to organise focus group interviews with expert members from different ethnic minority groups. Two criteria were used to identify 'expert members': the participants had to belong to an ethnic minority and they had to work for either a media or a minority group organisation. The expert members were invited to one of four focus group sessions organised in October 2017. In total, 12 people participated, of whom seven were women, all were between 22 and 55 years old, and all had different ethnic origins (including the Far and Middle East, Northern and sub-Saharan Africa, and Eastern Europe).

The focus group sessions had a duration between 1.5 and 2 hours. Each session started with a general and open discussion on media representations of diversity, during which each participant was asked to share his/her own experiences and perceptions. Next, we showed the participants up to seven short clips chosen on the basis of the content analysis and representative for the variety of ways in which TV journalists and producers deal with ethnic minority persons and topics in non-fiction programmes. We did not explain why we had selected those items, but neutrally stated that these were either typical or rare examples of how TV programmes approach and represent ethnocultural diversity. As we had expected, the clips elicited rich and nuanced conversations between participants on the pros and cons of diversity representations on Flemish television. The data derived from the focus groups helped us to further interpret the findings from the content analysis.

\section{Findings and Discussion}

Given that the results of this study are based on triangulation of findings derived from the content analysis and focus group interviews, we present our findings and in- sights in an integrated way. Following the structure of the above literature review, our analysis is organised around the three themes of under-representation, stereotypical and negative representations, and 'white normativity' in ethnic minority coverage, leading us to a critical reflection on VRT journalists' and TV producers' sensitivity for super-diversity.

First, in relation to under-representation, it is important to note that the appearance of ethnic minorities on television is related to important events and debates in national and international politics. In the period of our study, events such as the Turkish coup attempt, the Syrian civil war, ISIS terrorism, and Europe's migration crisis have drawn much of the Flemish media attention to 'new Flemings' with origins in Turkey, the Maghreb countries, and the Middle East. Although our qualitative content analysis does not allow us to quantify this claim, data from the VRT's Diversity Monitor do confirm it, as does the overall perception of our focus group participants that minorities with roots in these regions dominate TV representations of ethnocultural diversity. Because of this observation, the first clips we showed in our focus groups featured 'new Flemings' with Moroccan and Turkish roots, leading one participant to state:

It's quite logical that people of Moroccan and Turkish origin begin to surface on television if you consider that the first generation of these communities immigrated fifty years ago. You may wonder how long it will take for the media to include the new migrant communities such as the Chechens or the Sudanese people.

In general, participants agreed that certain minorities, especially Muslims and people from the Middle East and (both Northern and sub-Saharan) Africa, seem to be more present on Flemish television, as compared to other ethnocultural minorities which tend to be underrepresented, such as Jews, migrants from Eastern European countries and people with origins in Asia except the Middle East. Some participants remarked that people belonging to under-represented groups still carry a 'burden of representation'. This was apparent in the content analysis as well, among others in a serene observational portrayal of an Orthodox Jewish family living in Antwerp. Despite the programme being 55 minutes long and several members of the Jewish family being interviewed on different topics, it stayed limited to one family. A focus group participant remarked that this particular family was 'an easy choice' made by the producers:

This man and his family are famous in Antwerp. This is one of the few Jewish families that often appear in the media, so they now somewhat stand for the entire Jewish community. You know, it's always him.

The issue of under-representation also persists when we focus on expert voices in news and current affairs programmes. The content analysis shows that ethno- 
cultural minority members still rarely appear in nonfiction programmes as experts on topics unrelated to their ethnocultural background. This was only the case in a few of our 36 analysed clips and episodes. However, there seems to be a difference between news and current affairs programmes, on the one hand, and talk shows and documentary programmes, on the other hand. For the latter genres, we found two examples of programmes centred around an ethnic minority person that went beyond identity-related topics, such as the glamourous portrayal of the Belgian-Iranian business women Attoesa in the programme Topservice or presenter Danira Boukhriss (Greek-Moroccan roots) teaching a class about love in De Klas. Similarly, the youth news programme Karrewiet contained items in which ethnic minority voices are included in relation to 'non-ethnic' topics, such as a young reporter covering the Dutch elections. In other news and current affairs programmes, we found that ethnocultural minority members occasionally appear in vox-pops or as celebrities, but not as expert voices, unless the item or programme focused on an issue related to their ethnocultural background. This finding aligns with the perception of the focus groups participants, one of whom stated:

When are you, as a Moroccan or Turk, contacted by the media? When they have an item about the festival of Eid al-Adha or some other typical Muslim phenomenon. But I never see, for instance, a Moroccan biologist on TV.

Another participant was surprised when she recently saw an IT-specialist of Turkish origin being interviewed in a TV news report about a worldwide cyber-attack, which to her shows that the VRT's diversity efforts start to pay off. Yet, she and other participants stressed that there is still much progress to be made in terms of representing 'diversity within diversity'. This is supported by our content analysis: looking at 'intersectionality', we found that ethnic minorities in non-fiction TV programmes rarely intersect with minority groups such as LGBTQ people, elderly people and people with disabilities. Little attention is also paid to religious diversity within ethnic groups (or to ethnic diversity within religious groups). Yet, these intersections are not completely absent. For example, the current affairs programme Terzake carried a report of a Syrian homosexual refugee studying in Brussels. Regarding the intersection between ethnicity and age, men older than 60 years old appeared in a report of Terzake, as well as in the investigative programme Pano and the docu-reality programme Goed Volk, whereas the oldest ethnic minority woman in the 36 analysed programmes and clips was 50 years old. Further, the human interest programme ledereen Beroemd carried an item about a blind person, while De Afspraak also had an ethnocultural minority interview guest with a visual disability. Although these exceptions were appreciated by the focus group participants, the lack of recognition for in- tragroup differences within ethnocultural minorities remains a point of concern, as reflected in the following quote, which focuses on the intersection between ethnicity and religion:

If you look at the TV coverage of Islamic topics, journalists don't see the difference between a Moroccan Muslim and a Persian Muslim. Yet, as a Moroccan, I have more in common with ethnic Belgians than with Iranian Muslims. A newsroom should be aware of the cultural and religious diversity within Islam.

Other participants criticised the VRT's current affairs programmes for always inviting the same experts, or as one participant put it, "there is more than just one scientist with Congolese roots who can give their opinion about what I call 'African-Flemish' topics or people".

The under-recognition of intragroup differences creates the image of ethnic minorities as rather homogeneous groups, which opens the door to stereotypical and negative representations, our second theme. Here, however, the qualitative content analysis and focus groups provide nuanced insights into the biases in media representations of ethnocultural diversity. For instance, by including different non-fiction genres and by purposively selecting items in which ethnic minorities appear in different roles and in relation to different topics, we were able to identify different examples that nuance the idea that ethnic minorities are commonly associated with 'bad news'. The negativity bias is clearly still dominant in the news coverage of politics and events related to ethnic minorities, but, as also indicated in the focus groups, most of these issues such as unemployment rates or discrimination, can and should not be ignored. What is more problematic, according to the participants, is that journalists and TV producers seem to struggle with avoiding clichés and stereotypes. The participants gave several other examples, many of which were in line with what our content analysis shows. One example of stereotyping in our sample was a report in the seven o'clock news about a training initiative to help recent immigrants find a job, that unnecessarily shifted the focus to the broader issue of unemployment among ethnic minorities by confusing the terms 'newcomers' (people who recently arrived in Belgium) and 'allochthones' (an unproductively broad category and a term to be avoided). Another news report, about the tendency among teenage football players to shower with their underwear on, included interviews with four young 'new Flemings', insinuating that this 'new puritanism' is primarily related to ethnicity, even though a sexologist interviewed in the same report argued that it had probably to do with the omnipresence of smartphone cameras.

Stereotyping does not only occur in textual representations, but also in visual representations of ethnic minorities in non-fiction programmes. One participant stated it explicitly: 
I still see much too many cliché representations of black people on television. You can see images of them happily dancing or hanging around in the street, but you seldom do see them in an intellectual role.

Although other participants agreed with her, our content analysis shows that the VRT programmes do also show ethnic minorities in less typical or stereotypical roles. For instance, a news item about Chinese New Year carried an interview with a westernised Chinese-Belgian woman instead of only showing exotic images of traditionally dressed Chinese people. Another news report, focusing on how people in a park enjoyed the first warm days of the season, started with interviews with white parents and their kids around the swimming pool, and then moved on to a Turkish-Belgian family taking a picnic elsewhere in the park, thus showing, in a unifying rather than differentiating way, how 'old' and 'new Flemings' spend their leisure time in the sun. Further, we observed several politicians with a migration background as voices in non-fiction TV programmes, as well as a dentist, a police agent, a business woman, and a writer. Again, our selective sample does not allow generalisation, but the examples show that the VRT does make efforts to move beyond stereotypes. These efforts and the good intentions were also acknowledged in the focus groups, although participants added that there is still considerable room for improvement.

Our third theme and an important remaining point of concern is the dominant group perspective. In our content analysis, this was for instance illustrated in the above-mentioned news item about unemployment among new migrants using the polarising term 'allochthone', ignoring the VRT's editorial guidelines suggesting avoidance of the term and generalising the problem of unemployment to all ethnic minorities. Another example concerns a news report about a day care centre for disadvantaged children. While most of its employees have a migration background, only 'white' employees were interviewed, and the journalist emphasised that the migrant employees lack a proper knowledge of the Dutch language. In the focus groups, this prevailing us/them dichotomy, and the underlying white normativity was perceived as a major problem for Belgian television. Apart from the newscasts, participants also directed their criticism at the current affairs programme De Afspraak. This programme regularly invites ethnic minority persons as interview guests to discuss the news of the day, but since they are placed around a table with the other three guests of the day, the 'new Flemings' remain a minority voice in the studio. In the focus groups, several participants remarked that often ethnic minority members are overruled by other interview guests or confronted with questions from the white, male TV presenter in such a way that it often puts them, intentionally or not, in the position of 'the other'. According to some participants, a perfect illustration was the clip we showed in which two black, female 'new Flemings' were invited for a discussion about daily racism in Flanders. Although one participant appreciated that the discussion was between two black persons "instead of white against black", most participants highlighted how it was embedded in a discourse of "us against them". As our content analysis shows, it already started with the introduction of the two guests as "two ladies, who both grew up in Flanders, both adopted out of Rwanda, both having two kids, you both went to the same school, I hear, yet with a totally different vision". Some participants interpreted this quote as a perfect example of the white normative perspective that views black people as one homogeneous group of whom 'we' thus can expect that 'they' would share one uniform vision.

Overall, our study shows that VRT journalists and TV producers seem to be aware of the issues and pitfalls of media representations of ethnocultural diversity, as we did not identify any very problematic (e.g., openly racist or stigmatising) representations. However, our analysis and the interviews with experts also showed that they regularly fall short of avoiding these pitfalls in the daily practices of TV production, making slippages (e.g., the occasional use of the word 'allochthone') and falling back on representational patterns (e.g., connecting ethnic minorities to certain themes or 'othering' them). At the end of the focus groups, participants were asked what the VRT could do to further increase cultural sensitivity among their staff. All of them underlined that it was crucial to increase diversity within the workforce. As one participant stated:

One of the problems is that the VRT still has 'white newsrooms', which makes that people with a minority background are not involved from the beginning of the creative process. Ideas and perceptions are sometimes counterchecked, but this often happens too late, when most decisions are already taken.

Other participants agreed by saying that ethnocultural sensitivity should become "a natural reflex" in every TV newsroom and production team, especially when covering stories with or about ethnocultural minorities. They stressed that a public service broadcaster should play a leading role in this process.

\section{Conclusion}

As argued in the literature review, the debate on PSM's role in representing ethnocultural diversity has shifted from the 'recognition of multiculturalism' towards the 'management of super-diversity'. Despite a growing awareness of this in newsrooms, the representation of ethnocultural diversity on television continues to be a permanent challenge and complex, multi-faceted issue for PSM. To critically evaluate the Flemish public service broadcaster's implementation of their diversity policies, this study employed a qualitative content analysis of the representation of ethnocultural diversity in 
non-fiction programmes, combined with focus group interviews with ethnocultural minorities.

The findings of our content analysis suggest that despite several measures undertaken by the VRT, the representation of ethnocultural minorities remains unbalanced and biased in at least three ways. First, despite some notable exceptions, minorities continue to be represented as homogeneous groups and their intragroup differences are insufficiently highlighted. This fits Cottle's (2000) argument that (public service) media should pay more attention to different 'intersections' between ethnicity and other identity factors such as age, gender, sexual orientation, religion, etc. Second, people with a migration background still largely appear in topics and issues related to their ethnocultural identity. This thematical 'typecasting' is in line with existing literature, and the focus group participants acknowledged that this is partly due to current affairs-often bad news-hence enforcing the negative stereotyping. However, journalists can counterbalance this bias by including ethnocultural minorities more often in non-ethnic-related topics, including expert roles. Third, minorities often continue to be portrayed and approached from a dominant group perspective, so they are 'othered' rather than included in Flemish society.

We do not want to suggest that the examples discussed are representative for the way in which ethnocultural minorities are being represented on Flemish television, as the qualitative nature of the study does not allow for generalisation. However, we contend that our findings indicate that there is still room for improvement in addressing the needs and interests of all social groups in a context of super-diversity. Yet, our study also makes clear that the VRT is aware of these issues and invests in efforts to improve ethnocultural diversity both in the workforce and in its programmes. The qualitative study at hand forms the basis for a series of workshops within the VRT to increase sensitivity for super-diversity among its employees and within its programmes, which may encourage them to engage more in 'listening across difference' and to question the professional pragmatics that shape their practices and strategies towards diversity management.

\section{Acknowledgments}

The authors would like to thank the staff members of the VRT Diversity Cell and the VRT Study Department, Geertje De Ceuleneer, Nadia Hanssens, Tomas Coppens and Wim Seghers, for the constructive meetings, assistance and feedback on the research project on which this study is based. We are also grateful to the participants of the focus groups.

\section{Conflict of Interests}

This study is part of a research project commissioned by the Flemish public service broadcaster VRT and indepen- dently carried out by the authors at the University of Antwerp. The authors declare no conflict of interests.

\section{References}

Blommaert, J., \& Verschueren, J. (1998). Debating diversity: Analysing the discourse of tolerance. London: Routledge.

Cottle, S. (1998). Making ethnic minority programmes inside the BBC: Professional pragmatics and cultural containment. Media, Culture \& Society, 20(2), 295-317. doi:10.1177/016344398020002008

Cottle, S. (2000). Media research and ethnic minorities: Mapping the field. In S. Cottle (Ed.), Ethnic minorities and the media (pp. 1-31). Buckingham: Open University Press.

Crenshaw, K. W. (1989). Demarginalizing the intersection of race and sex: $A$ black feminist critique of antidiscimination doctrine, feminist theory, and antiracist politics. University of Chicago Legal Forum, 140, 139-167.

d'Haenens, L. (2006). Media as managers of diversity. In L. d'Haenens, M. Hooghe, D. Vanheule, \& H. Gezduci (Eds.), 'New' citizens, new policies? Developments in diversity policy in Canada and Flanders (pp. 137-157). Gent: Academia Press.

Dhoest, A. (2014). Struggling with multiculturalism: Cultural diversity in Flemish public broadcasting policies and programming. In K. Horsti, G. Hultén, \& G. Titley (Eds.), National conversations: Public service media and cultural diversity in Europe (pp. 105-124). Bristol: Intellect.

Dhoest, A. (2015). Contextualising diversity in TV drama: Policies, practices and discourses. Series: International Journal of TV Serial Narratives, 1(2), 169-180. doi:10.6092/issn.2421-454X/5902

Dreher, T. (2009). Listening across difference: Media and multiculturalism beyond the politics of voice. Continuum: Journal of Media \& Cultural Studies, 23(4), 445-458. doi:10.1080/10304310903015712

Dwyer, C. (1998). Contested identities. Challenging dominant representations of young British Muslim women. In T. Skelton \& G. Valentine (Eds.), Cool places: Geographies of youth cultures (pp. 50-65). London: Routledge.

Dyer, R. (1997). White. London: Routledge.

Essed, P. (1991). Understanding everyday racism: An interdisciplinary theory. Newbury Park: Sage.

Ferguson, R. (1998). Representing 'race': Ideology, identity and the media. London: Arnold.

Gerbner, G., \& Gross, L. (1976). Living with television, the violence profile. Journal of Communication, 26(2), 173-199. doi:10.1111/j.1460-2466.1976.tb01397.x

Haynes, A. (2007). Mass media re-presentations of the social world: Ethnicity and 'race'. In E. Devereux (Ed.), Media studies: Key issues and debates (pp. 162-190). London: Sage.

Hodkinson, P. (2011). Media, culture and society: An in- 
troduction. London: Sage.

Horsti, K., Hultén, G., \& Titley, G. (2014). Introduction. In K. Horsti, G., C. Hultén, \& G. Titley (Eds.), National conversations: Public service media and cultural diversity in Europe (pp. 1-18). Bristol: Intellect.

Leurdijk, A. (2006). In search of common ground: Strategies of multicultural television producers in Europe. European Journal of Cultural Studies, 9(1), 25-46. doi:10.1177/1367549406060806

Malik, S. (2013). 'Creative diversity': UK public service broadcasting after multiculturalism. Popular Communication, 11(3), 227-241. doi:10.1080/ 15405702.2013.810081

Newman, N., Fletcher, R., Kalogeropoulos, A., Levy, D. A. L., \& Nielsen, R. K. (2017). Reuters Institute digital news report 2017. Oxford: Reuters Institute. Retrieved from www.digitalnewsreport.org/survey/ 2017

Noppe, J., Vanweddingen, M., Doyen, G., Stuyck, K., Feys, Y., \& Buysschaert, P. (2018). Vlaamse migratie- en integratiemonitor 2018 [Flemish migration and integration monitor 2018]. Brussel: Agentschap Binnenlands Bestuur.

Ofcom. (2017). Diversity and equal opportunities in television: Monitoring report on the UK broadcasting industry. London: Ofcom. Retrieved from www. ofcom.org.uk/_data/assets/pdf_file/0017/106343/ diversity-television-report-2017.pdf

Saeed, A. (2007). Media, racism and Islamophobia: The representation of Islam and Muslims in the media. Sociology Compass, 1(2), 443-462. doi:10.1111/j.17519020.2007.00039.x

Shadid, W. (2005). Berichtgeving over moslims en de islam in de westerse media: Beeldvorming, oorzaken en alternatieve strategieën [Muslims and Islam in western media]. Tijdschrift voor Communicatiewetenschap, 33(4), 330-346.

ter Wal, J., d'Haenens, L., \& Koeman, J. (2005). (Re)presentations of ethnicity in EU and Dutch domestic news: A quantitative analysis. Media, Culture \& Society, 27(6), 937-950. doi:10.1177/ 0163443705057681

Titley, G. (2014). After the end of multiculturalism: Public service media and integrationist imaginaries for the governance of difference. Global Media and Communication, 10(3), 247-260. doi:10.1177/ 1742766514552351

Van den Bulck, H., \& Broos, D. (2011). Can a charter of diversity make the difference in ethnic minority reporting? A comparative content and production analysis of two Flemish television newscasts. Communications: The European Journal of Communication Research, 36(2), 195-216. doi:10.1515/comm.2011.010

van Dijk, T. A. (2000). New(s) racism: A discourse analytical approach. In S. Cottle (Ed.), Ethnic minorities and the media: Changing cultural boundaries (pp. 33-49). Buckingham: Open University Press.

Vertovec, S. (2007). Super-diversity and its implications. Ethnic and Racial Studies, 30(6), 1024-1054. doi:10.1080/01419870701599465

VRT/Flemish Government. (2016). Beheersovereenkomst 2016-2020 tussen de Vlaamse Gemeenschap \& VRT [Management agreement 2016-2020 between the Flemish Community \& VRT]. VRT. Retrieved from www.vrt.be/nl/over-de-vrt/ beheersovereenkomst

\section{About the Authors}

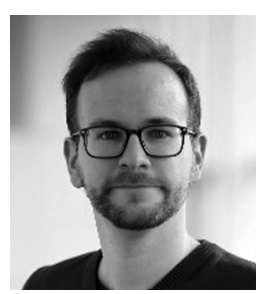

Koen Panis is a Postdoctoral Researcher and Guest Professor at the Department of Communication Studies and member of the Media, Policy and Culture research group at the University of Antwerp. His research focuses on media and popular culture, with a particular interest in celebrity studies and television studies, focusing on representation as well as audience reception. For a full CV and list of publications, see www.uantwerpen.be/koen-panis

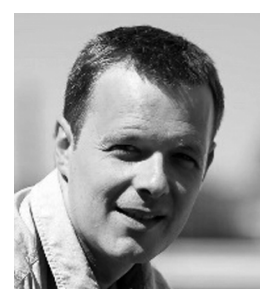

Steve Paulussen is Associate Professor in Journalism and Media Studies at the Department of Communication Studies and member of the Media, Policy and Culture research group at the University of Antwerp. His research focuses on changes in journalism, with a particular interest in newsroom innovation, participatory journalism and the relationship between news and social media. For a full CV and list of publications, see www.uantwerpen.be/steve-paulussen

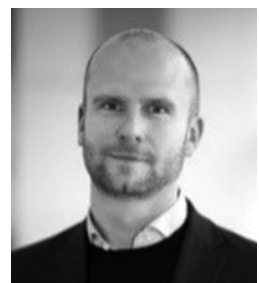

Alexander Dhoest is Professor in Communication Studies, vice-chair of the Department of Communication Studies and chair of the Media, Policy and Culture research group at the University of Antwerp. His research focuses on media (in particular television), identity and diversity, both on the level of representations and on the level of audiences. For a full CV and list of publications, see www.uantwerpen.be/alexander-dhoest 